\title{
Revisiting cellular immune response to oncogenic Marek's disease virus: the rising of avian T-cell immunity
}

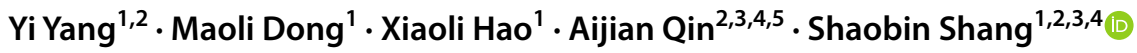

Received: 9 November 2019 / Revised: 6 February 2020 / Accepted: 7 February 2020 / Published online: 20 February 2020

(c) The Author(s) 2020

\begin{abstract}
Marek's disease virus (MDV) is a highly oncogenic alphaherpesvirus that causes deadly T-cell lymphomas and serves as a natural virus-induced tumor model in chickens. Although Marek's disease (MD) is well controlled by current vaccines, the evolution of MDV field viruses towards increasing virulence is concerning as a better vaccine to combat very virulent plus MDV is still lacking. Our understanding of molecular and cellular immunity to MDV and its immunopathogenesis has significantly improved, but those findings about cellular immunity to MDV are largely out-of-date, hampering the development of more effective vaccines against MD. T-cell-mediated cellular immunity was thought to be of paramount importance against MDV. However, MDV also infects macrophages, B cells and T cells, leading to immunosuppression and T-cell lymphoma. Additionally, there is limited information about how uninfected immune cells respond to MDV infection or vaccination, specifically, the mechanisms by which T cells are activated and recognize MDV antigens and how the function and properties of activated T cells correlate with immune protection against MDV or MD tumor. The current review revisits the roles of each immune cell subset and its effector mechanisms in the host immune response to MDV infection or vaccination from the point of view of comparative immunology. We particularly emphasize areas of research requiring further investigation and provide useful information for rational design and development of novel MDV vaccines.
\end{abstract}

Keywords Marek's disease virus $\cdot$ Cellular immunity $\cdot \mathrm{T}$ cells $\cdot$ Vaccines

Yi Yang and Maoli Dong have equally contributed to this work.

Aijian Qin

aijian@yzu.edu.cn

$\triangle$ Shaobin Shang

shaobinshang@yzu.edu.cn

1 Institute of Comparative Medicine, College of Veterinary Medicine, Yangzhou University, Yangzhou 225009, China

2 Jiangsu Co-innovation Center for Prevention and Control of Important Animal Infectious Diseases and Zoonosis, Yangzhou University, Yangzhou 225009, China

3 International Corporation Laboratory of Agriculture and Agricultural Products Safety, Yangzhou University, Yangzhou 225009, China

4 Ministry of Education Key Laboratory for Avian Preventive Medicine, College of Veterinary Medicine, Yangzhou University, Yangzhou 225009, China

5 Key Laboratory of Jiangsu Preventive Veterinary Medicine, Yangzhou University, Yangzhou 225009, China

\section{Introduction}

Marek's disease (MD) is a highly contagious and rapidly progressive lymphoproliferative disease of chickens characterized by neurological disorders and neoplastic transformation of $\mathrm{CD}^{+} \mathrm{T}$ cells and immunosuppression [1], which has a large economic impact on the poultry industry. The causative agent of MD is Gallid herpesvirus 2 (GaHV2), traditionally known as Marek's disease virus (MDV), a member of the genus Mardivirus of Alphaherpesvirinae subfamily. The other members in this genus are Anatid alphaherpesvirus 1 (AnHV-1), Columbid alphaherpesvirus 1 (CoHV-1), GaHV-3, Meleagrid alphaherpesvirus 1 (MeHV-1 or Herpesvirus of Turkey, HVT), and Spheniscid alphaherpesvirus 1 (SpAHV-1) according to the Report of International Committee on Taxonomy of Viruses (2019) [2]. GaHV-2, GaHV-3, and HVT correspond to previous serotypes of MDV-1, MDV-2, and MDV-3, respectively [3, 4]. GaHV-2 is oncogenic, while GaHV-3 and MeHV-1 are non-oncogenic, but can cause viremia after infection. Currently, the commercially available vaccines against MDV 
are CVI988/Rispens (hereafter referred to as CVI988) from GaHV-2, the SB1 strain from GaHV-3, and the HVT FC126 strain from MeHV-1 [5-7]. CVI988 is believed to be the most effective vaccine [8], while vaccine strain 814 with equivalent protective efficacy as CVI988 is also widely used in China [9]. Through large-scale vaccination programs, MD outbreaks have been controlled worldwide, making MD the first oncogenic disease that can be prevented by an effective vaccine $[1,10,11]$. However, to date, the protective mechanisms of the MDV vaccines have not been fully revealed. The current MDV vaccines do not induce sterilizing immunity despite protecting chickens from developing tumors. Thus, MDV field viruses can still establish infection in vaccinated chickens, and then replicate and shed fully infectious virions through skin dander and poultry dust. Therefore, it is believed that the wide use of MDV vaccines is driving the evolution of MDV field viruses toward greater virulence [1,11-14]. Indeed, virulent or very virulent plus MDV (vv+ MDV) field strains were documented to break through the protection conferred by CVI988 vaccine clinically or experimentally [14-18], highlighting a worry of the lack of a better alternative to CVI988 to combat increasingly virulent MDV strains in the future. Unfortunately, progress in developing such vaccines has been slow, since most MDV vaccines under development are no more efficacious or safer than CVI988 [19, 20]. Thus, it is imperative to dissect the immune protective mechanism of current MDV vaccines to design targeted MDV vaccines that can confer better protection against recurrent MDV infections. In addition, as MD is a natural virus-induced tumor model in chickens, investigating its immune response could be informative for tumor immunology.

The aim of this review article is to revisit the roles of each immune cell subset and their effector mechanisms in the host immune response to MDV infection or vaccination, with an emphasis on areas of research that need further investigation and to provide useful information for rational design and development of novel MDV vaccines.

\section{Cellular immunity to virus infections in mammals: a mirror for chickens?}

Effective control of a viral infection typically requires the coordination of innate and adaptive arms of the immune system. As the first line of defense, the innate arm includes granulocytes, monocytes, macrophages, and natural killer (NK) cells [21]. The adaptive arm includes B cells, T-helper cells, and cytotoxic T cells [21]. Dendritic cells (DCs) and unconventional T cells such as $\gamma \delta \mathrm{T}$, natural killer T (NKT) cells, and mucosal-associated invariant T cells (MAIT) $[22$, 23] are at the cusp of the innate and adaptive arms, bridging the two wings of immunity.
Once a virus establishes an infection in the host, it hijacks the protein-synthesis machinery of host cells to generate virion progeny. During the early stage of this process, type I interferon (IFN- $\alpha / \beta)$ and inflammatory cytokines as well as chemokines are triggered via recognition of pathogen-associated molecular patterns (PAMPs) by pattern recognition receptors from target cells [24] and adjacent phagocytes that have taken up the virus or apoptotic target cells $[25,26]$. These cytokines activate NK-cells, macrophages, and DCs, which quickly inhibit viral replication, kill infected cells, or enhance virus clearance [26, 27]. Additionally, these cytokines also recruit more immune cells to the site of infection to cope with the virus, which in turn induces a more potent inflammatory response. In some cases, the innate immune response may be sufficient to control the viral infection. However, if this is insufficient, the adaptive immune response takes the stage [25, 28]. Viral particles or remnants of virally infected cells from extracellular sources are taken up by antigen-presenting cells and degraded into peptide fragments by the proteasome or in the endosome/lysosome, which are then loaded onto major histocompatibility complex (MHC) class I or class II molecules to form MHC-peptide complexes [29, 30]. The MHC-peptide complexes displayed on the surface of APC engage with T-cell receptors (TCR) on T cells. Together with co-stimulatory signals, this leads to activation and differentiation of T-cell subsets [21, 28]. This priming process initially occurs in regional draining lymph nodes close to the areas initially infected by the virus. Activated $\mathrm{CD} 8^{+} \mathrm{T}$ cells differentiate into effector $\mathrm{T}$ cells, producing cytokines such as interferon gamma (IFN- $\gamma$ ) and tumor necrosis factor alpha (TNF- $\alpha$ ) as well as cytotoxic granules including granzymes, perforin, and granulysin to induce programmed death of virus-infected target cells [31]. TNF- $\alpha$ can trigger apoptosis of infected target cells by interacting with TNF receptor I [32], while IFN- $\gamma$ is able to induce an antiviral state in uninfected cells and enhances the cytotoxicity of $\mathrm{CD} 8^{+} \mathrm{T}$ cells [33]. Activated $\mathrm{CD} 4^{+} \mathrm{T}$ cells can produce a wide range of cytokines and chemokines, and can even express cytotoxic functions themselves [34]. Based on cytokine production and lineage differentiation, $\mathrm{CD} 4^{+} \mathrm{T}$ cells can be divided into T-helper 1 (Th1), T-helper 2 (Th2), T-helper 17 (Th17), regulatory T cells (Treg), follicular helper $\mathrm{T}$ (Tfh), and T-helper 9 (Th9) [35]. Th1 cells are generally characterized by the production of IFN- $\gamma$. Th2 cells mainly produce interleukin (IL) 4, IL-5, and IL-13, while Th17 cells exclusively express IL-17 [35]. Treg cells, characterized by the production of IL- 10 and expression of TGF- $\beta$, modulate the immune response by dampening inflammatory responses and limiting immunopathology $[28,36]$. In addition, activated $\mathrm{CD} 4{ }^{+} \mathrm{T}$ cells (Th1 and $\mathrm{Tfh}$ ) can provide "help" to $\mathrm{CD} 8^{+} \mathrm{T}$ cells and $\mathrm{B}$ cells through the interaction of CD40-CD40L which leads to the up-regulation of co-stimulatory molecules CD80 and CD86 on DCs and their interaction with CD28 on naïve $\mathrm{T}$ cells, promoting cytotoxic $\mathrm{CD} 8^{+} \mathrm{T}$-cell activation [37], 
and to the survival, proliferation, and immunoglobulin class switching of B cells [28, 38]. In addition to MHC-peptide-TCR engagement, T cells can also be indirectly activated by IL-12 and IL-18 generated by activated APCs or from microenvironment $[39,40]$.

After acute viral infection, a small frequency of activated $\mathrm{T}$ cells develops into antigen-specific, long-lasting central memory $\mathrm{T}$ cells $\left(\mathrm{T}_{\mathrm{CM}}\right)$. Upon secondary infection, memory $\mathrm{T}$ cells can rapidly proliferate and differentiate into secondary effector $\mathrm{T}$ cells to combat infection [41-43]. The development and maintenance of $\mathrm{T}_{\mathrm{CM}}$ is highly associated with the efficacy and duration of protection conferred by vaccines [ 43 , 44]. However, if viral infection persists, activated T cells will not differentiate from effector $\mathrm{T}$ cells into $\mathrm{T}_{\mathrm{CM}}$. These effector $\mathrm{T}$ cells will up-regulate co-inhibitory molecules, such as programmed cell death protein 1 (PD-1) and killer cell lectin-like receptor subfamily G member 1 (KLRG1) and gradually lose the ability to proliferate and produce cytokines due to persistent antigenic and inflammatory stimulation (namely T-cell exhaustion). Exhausted T cells are generally characterized by poor recall responses upon re-encountering the same pathogen $[45,46]$.

In contrast to our knowledge of antiviral immunity in mammals, we have a limited understanding of antiviral immunity in birds, especially cellular immunity. Although the immune system of chickens largely resembles that of mammals, chickens display some unique features, including a lack of lymph nodes, a unique organ for B-cell development, the so called "minimal essential MHC", and a reduced repertoire of cytokines and chemokines [47, 48]. In the absence of a lymphatic draining system, DCs can activate T cells locally without the need to migrate to lymph nodes for T-cell priming, which is required in mammals. At the cellular level, in addition to macrophages, DCs, B cells, and T cells, chickens have distinct immune cell subsets compared to mammals, such as heterophils, a heterogenous subset comprising of neutrophils and macrophages, nucleated thrombocytes, and an extraordinarily high proportion of $\gamma \delta$ T cells [47]. These differences may imply that the kinetics of the cellular immune response, antigen presentation, and T-cell activation, and the function of effector cells may differ from mammals in response to MDV infection. For instance, MDV antigen-specific CTLs and avian influenza virus (AIV)specific IFN- $\gamma$-producing $\mathrm{T}$ cells can be detected in chickens at 7 days post-infection (dpi) [49-52], which is much earlier than that observed in mice after viral infection.

\section{The roles of different cellular subsets during MDV infection}

MDV is a strictly cell-associated virus. T-cell-mediated immunity is thought to play a more important role compared to antibody-mediated response. However, due to lack of immunological reagents, MDV-induced cellular immune responses have not been comprehensively characterized at single-cell level in chickens. While MDV-infected macrophages, $\mathrm{B}$ cells and $\mathrm{T}$ cells were documented to contribute to immunosuppression, and T-cell lymphoma, macrophages, NK cells, $\gamma \delta$ T cells, B cells, T-helper cells, and cytotoxic $\mathrm{T}$ cells have also been shown to participate in host immune response to MDV. Nevertheless, the roles of DCs, heterophils, thrombocytes, and NKT cells have not been documented during MDV infection (as reviewed below).

\section{Macrophages and DCs}

Macrophages are the most studied phagocytes of the avian immune system and during MDV infection. Activation of chicken macrophages with pathogen-associated molecular patterns (PAMPs) such as TLR ligands and/or IFN- $\gamma$ leads to increased phagocytic activity, secretion of cytokines and chemokines, and production of nitric oxide and reactive oxygen species [47]. Based on in vitro and in vivo studies, macrophages play a dual role in the pathogenesis of MDV and immunity against MDV [53-55].

In the early stage of MDV infection, some macrophages support cytolytic replication of MDV as indicated by the expression of three herpesvirus kinetically expressed antigens, ICP4 (immediate early), pp38 (early), and gB (late) in these cells [53]. MDV-infected macrophages can pass the virus to other cells and this process has recently been reproduced by an in vitro infection model of phagocytes [56]. However, macrophages that have phagocytosed MDVinfected cells are not infected and do not express those antigens [53], suggesting that macrophages are capable of inhibiting MDV replication. Indeed, in vitro studies showed that depletion of splenic macrophages increases MDV replication [57], whereas induction of peritoneal macrophages in vivo using thioglycollate broth can reduce the incidence of MD [58].

The ability of macrophages to inhibit MDV replication depends on its activation state, as macrophages isolated from naïve chickens are less efficient in inhibiting MDV replication than those from infected chickens [55]. Activated macrophages can exert their antiviral activities through production of NO induced by inducible nitric oxide synthase (iNOS). Up-regulation of iNOS after MDV infection has been documented in the spleen, brain, and lung of infected chickens [59-62], and higher concentrations of NO are associated with greater inhibition of MDV replication [55, 60, 62]. Vaccination with CVI988 induced activation of splenic macrophages and activated splenic macrophages from MDresistant chickens expressed higher level of IFN- $\gamma$, IL-6, and IL-12 mRNA than that of MD-susceptible chickens at $3 \mathrm{dpi}$ but not at $5 \mathrm{dpi}$, though the number of macrophages increased at 5 dpi in both lines [63]. However, the expression 
of iNOS and phagocytic activity of these vaccine-activated macrophages were not examined in this study. As both IFN- $\gamma$ and TNF- $\alpha$ can activate macrophages to express iNOS and NO through different signaling pathways [64] and chicken TNF- $\alpha$ was recently discovered and cloned [65], it remains to be determined which cytokine could play a dominant role in the activation of macrophages after MDV infection. By comparing the transcriptome of bone marrow-derived macrophage from MD-resistant and -susceptible chicken lines $\left(6_{1}\right.$ and $7_{2}$, respectively) pre- and post-infection with CVI988 carrying a GFP reporter, Chakraborty et al. found that the intrinsic and responsive resistance in macrophages from these two inbred chicken lines is related to the differences in differentially expressed genes profiles, especially in the expression of immune-related genes (for instance, high expression of iNOS pathway and IL-6 and reduced expression of IL-18), activation of biological signaling pathways, and suppression of oncogenic potential (such as tumor-suppressor gene RASEF and a gene CLDN5 involved in formation of tight junctions) [66]. In addition to the antiviral ability of macrophages, it was found that splenic macrophages from MDV-infected chickens could suppress mitogeninduced proliferation of splenocytes [67]. This finding led to a postulation that tumor-associated macrophages (TAMs), a population of macrophages with immunosuppressive and pro-tumoral function identified in many tumors [68], may be involved in MDV-induced immunosuppression [10]. However, those immunosuppressive splenic macrophages might be myeloid-derived suppressor cells instead as they were identified in the early stage of MDV infection (7 dpi), at which time MDV-induced tumors had not yet developed [67]. A potential role of TAMs in MDV-induced T-cell lymphoma remains to be elucidated.

DCs play a central role in the initiation of adaptive immune responses, efficiently presenting antigens to $\mathrm{T}$ cells. Although chicken bone marrow-derived DCs can be cultured in vitro with recombinant chicken granulocyte-macrophage colony-stimulating factor (GM-CSF) and IL-4 [69] and chicken DCs such as Langerhans cells [70], respiratory phagocytes [71], and conventional DCs (cDC) [72] were defined in vivo by surface markers including putative CD11c (clone 8F2), 74.3, CD83, CD86, MHC-II, KUL01, and DEC205 [69-73], there is no information on the type and function of DCs in the initiation of adaptive immunity against MDV in chickens. There is still a gap in the knowledge of how DCs present MDV antigens to prime T cells. However, up-regulation of IL-12 and IL-18, two cytokines critical for polarizing and activating Th1 cells [40,74], has been frequently observed in the innate immune response to MDV infection and CVI988 vaccination $[63,75,76]$. It is unclear whether these cytokines are secreted by DCs or other APCs and how these cytokines shape T-cell-mediated immunity after MDV infection or vaccination.

\section{Natural killer cells}

NK cells are innate immune cells that destroy virally infected or transformed cells, playing an important role in the early defense against intracellular pathogens or tumors. Their activation is determined by the balance between the activating and inhibitory receptors on NK cells, many of which are structurally related to the molecules of major histocompatibility complex class I (MHC-I) [77]. NK cells can kill target cells by secretion of cytolytic granules containing perforin and granzymes or by ligation of death domain-containing receptors. They can also produce cytokines such as IFN- $\gamma$, TNF- $\alpha$ and GM-CSF, exhibiting immune-modulatory activities [77].

An early study performed by Sharma et al. showed that splenocytes from uninfected or MDV-infected chickens have natural killer activity on the LSCC-RP9 B lymphoblastoid cell line and the MDCC-MSB1 cell line, which is resistant to T-cell depletion by anti-thymocyte serum, indicative of a role of NK cells during MDV infection [78]. Based on this, an increased activity of NK cells was associated with resistance to $\mathrm{MD}$ when comparing vaccinated MD-resistant B21 with MD-susceptible B19 chicken lines [52, 78, 79]. Of note, both infection with MDV and vaccination with HVT or SB1 increased NK-cell cytotoxicity of splenocytes [79]. However, in both cases, NK-cell activity peaked at $7 \mathrm{dpi}$ and then waned quickly $[52,79]$. Due to technical limitations, the identity of NK cells in the above-mentioned studies was not defined. Studies from comparative immunology showed that chicken NK cells, mainly defined by $\mathrm{CD} 8 \alpha^{+} \mathrm{CD} 3^{-}$[80], are initially found in the embryonic spleen and intestinal epithelium, but not in blood. Recently, NK cells were identified in blood using CD56 and CHIR-AB1 markers [81] and in spleen and lung by other specific monoclonal antibodies (mAbs) with low frequency [82]. Even though the expression of cytotoxicity-associated genes including granzyme A, $N K$-lysin, and perforin were detected and increased in birds after MDV infection [83], it was not addressed whether these effector molecules were produced by NK cells. It should be noted that other innate-like T cells, such as $\gamma \delta \mathrm{T}$ cells, may contribute to the expression of granzyme/perforin as they were found to spontaneously express those effector molecules in chickens [84]. However, a recent study clearly showed that primary NK cells from chicken embryonic spleen are activated when co-cultured with MDV-infected chicken embryo cells in vitro, expressing CD107, a surrogate marker of cytotoxicity, and IFN- $\gamma$ as measured by flow cytometry [85]. Surprisingly, primary NK cells are also efficiently infected by MDV RB1B and CVI988 in the coculture setting and the oncogenic meq gene of MDV was shown to contribute to the enhanced NK-cell activation [85]. Although down-regulation of MHC-I surface expression is a characteristic of MDV infection [86, 87], which could lead 
to NK-cell activation [77], MDV may also evade NK surveillance. It was shown that MDV prevented the down-regulation of MHC molecule BF1 that specifically interacts with NK cells, thereby inhibiting NK-cell activation [88]. Overall, although NK cells are thought to contribute to the early protection conferred by MDV vaccines, it is unclear how much protection NK cells could mediate after vaccination.

\section{$\delta$ T cells}

$\gamma \delta \mathrm{T}$ cells are non-conventional lymphocytes with a restricted TCR repertoire having properties of innate immune cells. They are pre-activated and can rapidly respond to infection or cytokine stimuli in a non-MHC-restricted manner [89], placing them at the interface of innate and adaptive immunity. $\gamma \delta \mathrm{T}$ cells can produce a wide range of cytokines such as IFN- $\gamma$ and IL-17A that orchestrate the immune responses and also exert direct cytotoxicity against infected and transformed cells by the release of granzymes and perforin and by the engagement of Fas- and TNF-related apoptosis-inducing ligand (TRAIL) receptors, respectively [89].

Unlike humans and mice, chickens belong to a group of animals that have high frequencies of $\gamma \delta \mathrm{T}$ cells. The frequency of $\gamma \delta \mathrm{T}$ cells in chickens can reach up to $50 \%$ of total circulating T cells and their TCR repertoires are much more diverse than that of humans and mice [48]. Recently, the potential role of $\gamma \delta \mathrm{T}$ cells during MDV infection was characterized [90]. The results showed that $\gamma \delta \mathrm{T}$ cells significantly increased in spleens and decreased in cecal tonsils at 10 and $21 \mathrm{dpi}$. These $\gamma \delta \mathrm{T}$ cells up-regulated expression of IFN- $\gamma$ in the early stage of infection and IL-10 during the later phases [90]. However, the information from this study is very limited. Interestingly, chicken $\gamma \delta \mathrm{T}$ cells were found to represent a major spontaneously cytotoxic subset that killed LSCC-RP9 cells in a MHC-unrestricted manner resembling NK cells [84] and these cells were also shown to express IL-17A [91]. Further studies are needed to identify whether chicken $\gamma \delta \mathrm{T}$ cells express other cytotoxic effector molecules or IL-17 during MDV infection. In addition, whether chicken $\gamma \delta \mathrm{T}$ cells play a critical role in the early protection conferred by CVI988 vaccine remains to be clarified.

\section{B cells}

For a long time, B cells have been thought to play a central role in the pathogenesis of MDV [92]. Based on the accepted model of the MDV life cycle, after inhalation of cell-free virus particle within contaminated dust and dander, epithelial cells are infected first, followed by phagocytes like macrophages and DCs [4]. At this time, B cells, along with T cells, are recruited to the lung by MDV-encoded viral IL-8, a functional orthologue of chemokine CXCL13L1 but distinct from chicken IL-8 $[93,94]$, which recognizes the C-X-C chemokine receptor type 5 (CXCR5) on B and T cells and induces chemotaxis [94]. Subsequently, B cells become the primary target cell for productive MDV replication after the virus is carried to lymphoid tissues by infected macrophages and DCs. B cells were shown to constitute around $90 \%$ of cytolytically infected cells, while $\mathrm{CD} 4^{+}$and $\mathrm{CD} 8^{+} \mathrm{T}$ cells represented only $8 \%$ and $3 \%$, respectively, as determined by pp38 expression when virus replication peaked between 3 and 7 dpi $[95,96]$. Consequently, B cells became apoptotic and depleted in the bursa, leading to B-cell lymphopenia in the blood [97]. In the interim, the virus is transferred from $\mathrm{B}$ cells to $\mathrm{T}$ cells, leading to the establishment of latency and transformation [98]. Indeed, this process was recapitulated in vitro by the co-culture of MDV-infected B cells with $\mathrm{CD}^{+}{ }^{+} \mathrm{T}$ cells [99]. However, other studies showed that the depletion of B cells by chemicals [100], X-ray irradiation, and/or surgical removal of the bursa of Fabricius [98, 101] did not consistently lead to the reduction in viral replication in chickens [92], rendering the role of B cells in MDV pathogenesis inconclusive. Recently, using Ig heavy chain J gene segment knockout (JH-KO) chickens that are deficient in mature and peripheral B cells, Bertzbach et al. showed that in the absence of B cells, viral load in the blood of infected animals was not altered. Disease and tumor incidence in JH-KO chickens were comparable to wild-type animals, and MDV readily infected $T$ cells and efficiently replicated in the lymphoid organs, leading to the transformation of $\mathrm{T}$ cells [92]. These results demonstrated that B cells are dispensable for viral replication, dissemination, and tumorigenesis [92].

Although B cells are productively infected by MDV, antibodies against MDV glycoprotein were generated by B cells and have been implicated in the immunity against MDV [1]. Anti-gB, -gE and -gI antibodies have been detected in MDVinfected chickens, among which anti-gB antibodies showed neutralizing activity and, thus, may play a protective role by blocking the entry of cell-free virus into the host cells [1, 102]. Passive transfer of anti-MDV sera from dam to naïve chickens in the first 4 days before challenge reduces the amount of viral antigens in tissues, the frequency of clinical signs, and the numbers of virus-infected cells, but cannot prevent infection $[1,103]$. In the setting of vaccination, single and repeated vaccination with HVT or CVI988 both induced neutralizing antibodies, with higher titers in the latter vaccination protocol [104]. While maternal antibodies from vaccinated hens were shown to reduce viral replication, mortality, and the severity of MD symptoms in the offspring after MDV infection [1, 105, 106], it was also reported to reduce vaccine efficacy of homologous vaccine strain [105].

Given that MDV is a cell-associated herpes virus and its transmission in vivo depends on cell-to-cell contact, it is speculated that antibodies to MDV may take effect only at the entry of cell-free virus into the host cells during early 
infection. Thus, B-cell-mediated humoral immunity might play a minimal role in protective immunity against MDV. Of note, the availability of JH-KO chickens could help to conclusively address this question [92].

\section{$\mathrm{CD4}^{+}$and $\mathrm{CD}^{+} \mathrm{T}$ cells}

Antibody and T-cell-mediated immunity play dominant roles in host defense against human alphaherpesviruses including herpes simplex virus type 1 (HSV-1), herpes simplex virus type 2 (HSV-2), and varicella zoster virus (VZV) [107]. MDV, as a highly cell-associated alphaherpesvirus, has some similarity with human alphaherpesvirus in certain aspects such as infection of APCs or $\mathrm{CD} 4^{+} \mathrm{T}$ cells, cell-tocell transmission, and reactivation after a period of latency [107]. However, for aforementioned reasons, antibodies play a minimal role and it is believed that T-cell-mediated immunity is more important than antibody-mediated humoral immunity in the control of MD in chickens [10]. Although it is well established that cytotoxic $\mathrm{CD}^{+} \mathrm{T}$ cells and cytokineproducing $\mathrm{CD}^{+}{ }^{+}$helper $\mathrm{T}$ cells mediate antiviral immunity to human herpesvirus [107, 108], how these T cells mediate antiviral and/or anti-tumor immunity against avian herpesvirus MDV is poorly understood.

In an early study, Ross et al. demonstrated that sensitized splenocytes from chickens previously immunized with an attenuated MDV strain (40 and $50 \mathrm{dpi}$ ) inhibited plaque formation of MDV-infected leukocytes and chicken kidney cells in a T-cell-dependent manner [109]. Later, Sharma et al. not only showed that splenocytes isolated from chickens 7 days after vaccination with SB1 or HVT specifically killed the MD lymphoblastoid cell line (MSB-1) but not antigenically unrelated target cells (TLT), but also demonstrated that the killing was T-cell dependent [110]. These results suggest that both antiviral and anti-tumor T-cell immunity against MDV were induced. Indeed, immunization with inactivated MDV-infected kidney cells and MD lymphoblastoid cells both protected chickens from MD [111]. The former induced antiviral immunity that suppressed viral replication, but was unable to kill tumor antigen-bearing cells, while the later elicited anti-tumor immunity that prevented the development of MD tumors but not viral replication [111]. Unfortunately, the identity of the $\mathrm{T}$ cells was not characterized due to the lack of immunological reagents.

In 1998, Morimura et al. demonstrated an important role of $\mathrm{CD}^{+} \mathrm{T}$ cells in preventing MDV infection by depleting $\mathrm{CD} 8$ cells using monoclonal antibodies, which resulted in an increased MDV titer within $\mathrm{CD} 4{ }^{+} \mathrm{T}$ cells and a decreased survival rate of CVI988-immunized chickens after challenge $[112,113]$. More detailed studies performed by Omar and Schat showed that cytotoxic T lymphocytes (CTLs) in the spleen at $7 \mathrm{dpi}$ or post-vaccination were $\mathrm{CD} 8^{+} \mathrm{TCR} \alpha \beta^{+}$ $\mathrm{T}$ cells, not $\mathrm{CD}^{+}{ }^{+}$or TCR $1^{+}(\gamma \delta \mathrm{T})$ cells $[49,50]$. These
CTLs killed reticuloendotheliosis virus (REV)-transformed target cells expressing ICP4, gB, pp38, and Meq antigens of MDV, respectively [49, 50]. Subsequently, other studies identified the presence of $\mathrm{gC}-, \mathrm{gI}-, \mathrm{gE}$ - and $\mathrm{gK}$-specific cytotoxic TCR $\alpha \beta 1^{+} \mathrm{CD} 8^{+} \mathrm{T}$ cells in MDV-infected chickens that were elicited differentially in MD-resistant and susceptible chickens [114]. Further comparison of the kinetics of CTL activity showed that gB-specific and MHC-restricted CTLs peaked at $8 \mathrm{dpi}$ in both MD-resistant and susceptible chickens, but contracted faster in the latter [52].

To date, the role of $\mathrm{CD}^{+} \mathrm{T}$ cells after MDV infection or immunization remains elusive. Although Morimura et al. attempted to address the role of $\mathrm{CD} 4^{+} \mathrm{T}$ cells after CVI988 immunization by depleting $\mathrm{CD} 4^{+} \mathrm{T}$ cells, their role has not been determined in vaccine-induced protective immunity $[112,113]$, possibly because depletion of $\mathrm{CD}^{+} \mathrm{T}$ cells may also result in the deficiency of lymphoma cells that are transformed from MDV-infected $\mathrm{CD}^{+}{ }^{+} \mathrm{T}$ cells after challenge. Although MDV infection induces atrophy of thymus and apoptosis of infected $\mathrm{T}$ cells as determined by in situ TUNEL assay [97], CD $4^{+} \mathrm{T}$ cells significantly expand in the periphery after MDV infection $[97,115]$ and the percentage of infected $\mathrm{CD}^{+} \mathrm{T}$ cells (pp38+) is low compared to total infected lymphocytes $[95,96,99]$. Thus, it is very likely that uninfected $\mathrm{CD} 4^{+} \mathrm{T}$ cells are activated and participate in host defense against MDV after infection or vaccination.

Despite the fact that MDV antigen-specific CTLs have been detected [49, 50], antigenic determinants recognized by CTLs have never been identified. In an effort made by Schat and Xing, the location of some epitopes has been narrowed down to the $\mathrm{C}$-terminal domain of the $\mathrm{gB}$ antigen, but the exact epitope motif has not been identified [116]. Haq et al. screened overlapping peptide libraries spanning parts of the above antigens using splenocytes from vaccinated MDresistant and -susceptible chickens and found no responsive peptide covering $\mathrm{gB}$ and $\mathrm{pp} 38$ [11]. By analyzing eluted peptides that bound to MHC haplotypes of chickens, Sherman et al. determined the epitope motifs of MHC BF2 molecule expressed in both MD-resistant B21 and MD-susceptible B13 chickens and found many peptide motifs matched on MDV and other avian viral proteins, but none of them were experimentally confirmed [117]. Due to the promiscuity of MHC-II peptide-binding motifs, attempts to generate MHC class II tetramers of B19 and B21 haplotype for tracking antigen-specific CD4 T cells have not seen much success, because no CD4 epitopes could be identified for loading onto MHC-II protein [11, 118, 119]. A breakthrough in determining T-cell epitopes of MDV antigens would in turn help to develop MHC tetramer to track antigen-specific T cells. With bioinformatic tools in immune epitope database (IEDB.org), a few T-cell epitopes on $\mathrm{gH}$ and $\mathrm{gB}$ of MDV were predicted, but are yet to be tested ex vivo [120]. As for MD tumor-associated surface antigen (MATSA), there is 
not much information available in spite of being discovered several decades ago $[110,111,121]$ except the identification of CD30 [122]. Recently, with the aid of imaging mass spectrometry and proteomics, Pauker et al. discovered that several novel proteins including IFN- $\gamma$-inducible protein 30 and a 70-kD heat shock protein were differentially expressed in tumor tissue compared to surrounding tissue and naive $\mathrm{T}$ cells, suggestive of potential MDV tumor markers. However, CD30 overexpression were not confirmed in the tumor tissue in this study [123].

In addition to cytotoxicity, $\mathrm{T}$ cells can also exert effector functions by secreting cytokines. IFN- $\gamma$ is a major cytokine produced by $\mathrm{T}$ cells and plays critical roles in antiviral immunity. The expression of IFN- $\gamma$ was increased in the spleen after MDV infection and inhibited MDV replication by inducing nitric oxide production [62]. Compared with unvaccinated chickens, the expression level of IFN- $\gamma$ mRNA was higher in CVI988-vaccinated chickens after challenge $[75,124]$. Co-administration of chicken IFN- $\gamma$ recombinant expression vector with HVT vaccine reduced the incidence of MD and enhanced the potency of HVT against MDV [125], indicating that IFN- $\gamma$ is a key factor in the protection against MD [75, 124]. However, the expression of IFN- $\gamma$ mRNA only peaked at 5 days post-vaccination and drastically decreased by day 10 after CVI988 vaccination [124]. By $21 \mathrm{dpi}$, there was no significant difference in the expression of IFN- $\gamma$ and IL-4 between HVT + SB 1 bivalent vaccinated and unvaccinated chickens [76]. As both T cells and NK cells are able to produce IFN- $\gamma$, it was unclear whether the IFN- $\gamma$ expression detected in these studies was from $\mathrm{T}$ cells or NK cells due to lack of reagents to track the cells. Detection of cytokine gene expression in sorted $\mathrm{CD}^{+}{ }^{+}$and $\mathrm{CD}^{+}{ }^{+} \mathrm{T}$-cell subsets showed that the expression of IFN- $\gamma$, IL-6, IL-10, and IL-18 were up-regulated in T cells at 4 and $21 \mathrm{dpi}$ [126]. However, there is a lack of association between the expression levels of these genes in splenic CD4 ${ }^{+}$ and $\mathrm{CD}^{+}{ }^{+} \mathrm{T}$ cells with the resistance and susceptibility of chickens to MD [127]. In addition, granzyme A and perforin, two effector molecules related to T-cell and NK cytotoxicity, continuously increased at the mRNA level by day 10 after CVI988 vaccination, indicating the possible priming of CTL [124]. However, these T-cell effector molecules were only examined in the early stage of infection, and their expression profiles at the late phase of MDV infection remain elusive.

Despite the effectiveness of current MDV vaccines in control of MD, they do not induce sterilizing immunity, leading to the persistence of MDV field viruses and vaccine strains. How persistent infection shapes T-cell function has not been investigated after MDV infection or vaccination. It is well established that chronic infection and many cancers cause $\mathrm{T}$-cell exhaustion, characterized by progressive loss of T-cell effector functions and memory properties, up-regulation of inhibitory receptors such as PD-1, lymphocyte activation gene 3 (LAG3), T-cell immunoglobulin and mucin domaincontaining protein 3 (TIM3), and cytotoxic T lymphocyte antigen 4 (CTLA-4) on T cells [128]. PD-1, as an immune checkpoint molecule, exerts immunoinhibitory effect on $\mathrm{T}$ cells upon engagement with its ligands, programmed deathligand 1 or 2 (PD-L1 or PD-L2). Signaling through PD-1 keeps activated $\mathrm{T}$ cells from killing tumor cells or infected target cells in the setting of persistent infection and cancers, and thus regulates the balance between T-cell activation, tolerance, and immunopathology [129]. Indeed, MDV infection up-regulates the mRNA expression of CTLA-4, PD-1, and PD-L1 in infected chickens [130, 131]. While mRNA expression of PD-1 was detected increased at the early cytolytic phase of infection [130] or on $\mathrm{CD}^{+}{ }^{+} \mathrm{T}$ cells of SPF birds at 21 dpi [131], PD-L1 expression increases at the latent phase. In addition, PD-1 and PD-L1 both increase in tumor lesions of MDV-infected chickens [130, 131]. However, it is unclear whether the up-regulation of PD-1-PD-L1 pathway is associated with T-cell dysfunction in vivo and whether other immunoinhibitory molecules are also up-regulated during MDV infection.

In contrast to the paradigm of chronic infection and T-cell dysfunction, the persistence of vaccine-derived viral antigens in chickens is believed to be responsible for the immune protection induced by current MDV vaccines. Wu et al. found that vaccine-derived viral antigens are not persistent in chickens after vaccine viruses enter latency [104]. Repeated vaccination with the current MDV vaccines (CVI988 and Fc126) within 1 week can invoke two consecutive productive infections, which elicits superior protection against MDV than a single vaccination in term of longer temporary expansion of $\mathrm{CD} 8^{+}, \mathrm{CD} 4^{+}$, and $\mathrm{CD} 3^{+} \mathrm{T}$ cells, stronger proliferative activity of peripheral blood lymphocytes and higher levels of neutralizing antibody [104], suggesting that productive antigen supply after vaccination favors induction of superior immunity against MD.

\section{Regulatory T cells}

Regulatory $\mathrm{T}$ cells (Treg) are a subset of $\mathrm{CD} 4^{+} \mathrm{T}$ cells that are critical for maintenance of immune homeostasis and selftolerance and their development is dictated by the expression of transcriptional factor Foxp3 [132]. They can exert immuno-regulatory function by the secretion of immunosuppressive soluble factors such as IL-10 and TGF- $\beta$, cell contact-mediated regulation through co-stimulatory molecules such as CTLA-4 as well as cytolytic activity [132]. Chicken Treg cells are functionally defined by $\mathrm{CD} 4{ }^{+} \mathrm{CD} 25^{+} \mathrm{T}$ cells that are present in most tissues including the thymus [133]. Foxp3 gene was not found in most avian genomes [134], probably due to low quality of avian genomes. But recently, 
a Foxp3 like gene was evident in the genomes of two avian species [135]. In the context of MDV infection, a potential role of Treg cells has been indicated as the expression of IL-10 and CTLA-4 regulatory molecules increased on CD4 ${ }^{+}$ $\mathrm{T}$ cells at 10 and $21 \mathrm{dpi}$, and this effect was more pronounced in the MDV-susceptible chicken lines [127, 131]. MDVinduced viral IL-8 can preferentially recruit $\mathrm{CD} 4{ }^{+} \mathrm{CD} 25^{+} \mathrm{T}$ cells [93]. Recently, Gurung et al. further identified a novel subset of Treg cells that express TGF- $\beta$ on the surface of the cells (TGF- $\beta^{+} \mathrm{CD} 25^{+} \mathrm{CD} 4^{+}$) in different lymphoid tissues, especially in the cecal tonsil [136]. The frequency of this population is higher in the spleens of MDV-susceptible chicken lines than in the resistant line, suggesting an association between TGF- $\beta^{+}$Treg cells and host susceptibility to lymphoma formation. Furthermore, this subset is induced by infection with virulent MDV, not by a vaccine strain, which can be detected in the lungs as early as $4 \mathrm{dpi}$. The transformed lymphoma cells also expressed high levels of TGF- $\beta$ that is involved in immunosuppression. These studies demonstrated that Treg cells are involved in pathogenesis and immunosuppression of MDV infection [136]. Recently, Gimeno et al. found that vv + MDV are highly immunosuppressive in commercial meat-type chickens, inducing severe cell death and unresponsiveness of splenocytes to Concanavalin A stimulation, which did not occur after infection with $\mathrm{v}$ or vvMDV strains [137], suggesting that vv + MDV may induce excessive immunosuppression. Whether vv+MDV induces more TGF- $\beta^{+}$Treg cells that contribute to such severe immunosuppression has yet to be determined.

\section{Perspectives and conclusions}

Although our understanding of molecular and cellular immunity to MD and its immunopathogenesis has significantly improved, much of those discoveries were from 2 decades ago. What we have learned about cellular immunity against MDV was out-of-date and not very informative due to limitations of immunological techniques and reagents in birds in the past. From the point of view of comparative immunology between MDV infection in birds and chronic viral infection in mice and humans, there are three pivotal questions involved in innate and adaptive immunity to MDV that need to be addressed: (1) How does each cellular subset dynamically respond to MDV infection or vaccination in addition to their roles in pathogenesis? (2) How are T cells activated and how do they recognize MDV antigens? (3) What are the functions and properties of activated $\mathrm{T}$ cells, and which phenotype of T cells correlates with immune protection against MDV or MD tumor?

Due to the lack of immunological reagents, determining the dynamic changes and functions of immune cells at a single-cell level after MDV infection has been challenging.
Although it is known that MDV-infected macrophages, DCs, $\mathrm{B}$ cells and $\mathrm{T}$ cells, eventually leading to immunosuppression and lymphoma, the roles of uninfected corresponding immune cells have not been properly defined. It is also unclear which antigen-presenting cell, macrophage or DC, infected APCs or uninfected APCs but carrying MDV antigens are responsible for early T-cell activation. In addition, whether T-helper cells other than Treg such as Th17, Th9, and $\mathrm{Tfh}$ are present and play roles in anti-viral or anti-tumor immunity to MDV has yet to be explored.

In general, there is a lack of comprehensive understanding of effector molecules expressed by activated $\mathrm{T}$ cells and NK cells after MDV infection or vaccination. With the qPCR as previously reported $[75,76,124]$, it was not possible to differentiate which cytokine was produced from particular immune cell subsets. Additionally, no peptide epitopes, recognized by MDV-specific T cells, have been identified. Since there are no generalized target cells for CTL assays, scientists have used REV-transformed and MDV antigentransfected cells for MHC-restricted CTL assays [52], which are complicated and not readily available. This hampers the evaluation of CTL activity induced by novel vaccines and further identification of T-cell epitopes. Failure to generate and maintain T-cell lines or CTL clones in vitro is another obstacle for these purposes. Whether memory $\mathrm{T}$ cells are generated and maintained after MDV infection or vaccination is unknown, especially since MDV and vaccine strains are not completely cleared in chickens. In addition, whether the up-regulated expression of inhibitory receptors impairs T-cell function and facilitates immune evasion of MDVtransformed CD4 $\mathrm{T}$ cells has yet to be investigated. Of note, most studies have been done in SPF chicken with $\mathrm{v}$ or vvMDV, whereas vv+ MDV are known to be more immunosuppressive in commercial chickens [137] and their effect on the immune response might differ from what has been found in SPF chickens. Thus, conducting studies on commercial chickens with vv+MDV is imperative to dissect immune mechanisms and develop better methods of control. Finally, although mass vaccination of poultry flocks has been implemented for over 40 years, our understanding of the protective mechanisms of these vaccines is still very limited. By analyzing the function and phenotype of antigen-specific $\mathrm{T}$ cells, we could define the correlates of immune protection, which may directly impact the success of developing a rational and highly efficacious MDV vaccine in the future.

While research on avian T-cell immunity to viruses is still constrained by a few of factors [138], significant advances in immunological reagents and methods have been achieved. The application of flow cytometry has enabled us to study the kinetics of immune cells in chickens at a single-cell level $[139,140]$ and to quantify absolute cell numbers by overcoming the interference of nucleated erythrocytes and 
Table 1 Updates on methods for investigating cell-mediated immunity in chickens

\begin{tabular}{|c|c|c|}
\hline Methods & Purposes/description & References \\
\hline Bead-based cell count & $\begin{array}{l}\text { To quantify absolute numbers of white blood cells in blood using Trucount }{ }^{\circledR} \text { Beads and anti-chicken } \\
\text { CD45 antibody without removal of nucleated erythrocytes and thrombocytes }\end{array}$ & {$[141]$} \\
\hline Multi-color flow cytometry & $\begin{array}{l}\text { To phenotype immune cells using antibodies against chicken surface markers CD8 } \alpha, \mathrm{CD} 4, \mathrm{TCR} 1 \text {, } \\
\text { Bu1, Kul01, CD3, CD45, and thrombocyte marker K1 }\end{array}$ & [139-141] \\
\hline CD107a assay & $\begin{array}{l}\text { To examine surface expression of CD107a (LEP100, clone 5G10) on cytotoxic T cells as indicator } \\
\text { of CTL degranulation }\end{array}$ & {$[144]$} \\
\hline CTL assay & $\begin{array}{l}\text { Using splenocytes from immunized or naïve chickens as effector cells to kill REV-transformed and } \\
\text { MDV antigen-transfected cells for detecting MHC-restricted cytotoxicity and RP9 cells for detect- } \\
\text { ing nonspecific cytotoxicity of NK and } \gamma \delta \text { T cells }\end{array}$ & {$[52,84]$} \\
\hline Intracellular cytokine staining & $\begin{array}{l}\text { To detect IFN- } \gamma \text { expression of T cells upon antigen stimulation by intracellular staining with anti- } \\
\text { IFN- } \gamma \text { monoclonal (clone 5C.123.08 and mAb80) and polyclonal antibody }\end{array}$ & {$[142,143]$} \\
\hline IFN- $\gamma$ ELISPOT & $\begin{array}{l}\text { Using anti-chicken IFN- } \gamma \text { antibody pairs (clone } 5 \mathrm{C} .123 .08 \text { and } 5 \mathrm{C} .123 .02 \text { ) to quantify the number } \\
\text { of IFN- } \gamma \text {-secreting T cells upon stimulation with epitope peptides or viral antigens }\end{array}$ & {$[51,142]$} \\
\hline In vitro T-cell culture & $\begin{array}{l}\text { T cells that are activated in plate pre-coated with anti-TCR } 2 \text { monoclonal antibody and grow in IL-2- } \\
\text { and IL-18-containing medium are used for T-cell infection and proliferation assay }\end{array}$ & {$[74,99]$} \\
\hline $\mathrm{DC}$ and $\mathrm{M} \Phi$ differentiation & $\begin{array}{l}\text { Dendritic cells and macrophages are differentiated from bone marrow cells with GM-CSF and IL-4, } \\
\text { immunophenotyped by antibodies against surface markers CD11c, CD40, CD80, CD86, MHC-II, } \\
\text { and used for mixed lymphocyte reaction and antigen presentation assay }\end{array}$ & {$[69,71]$} \\
\hline
\end{tabular}

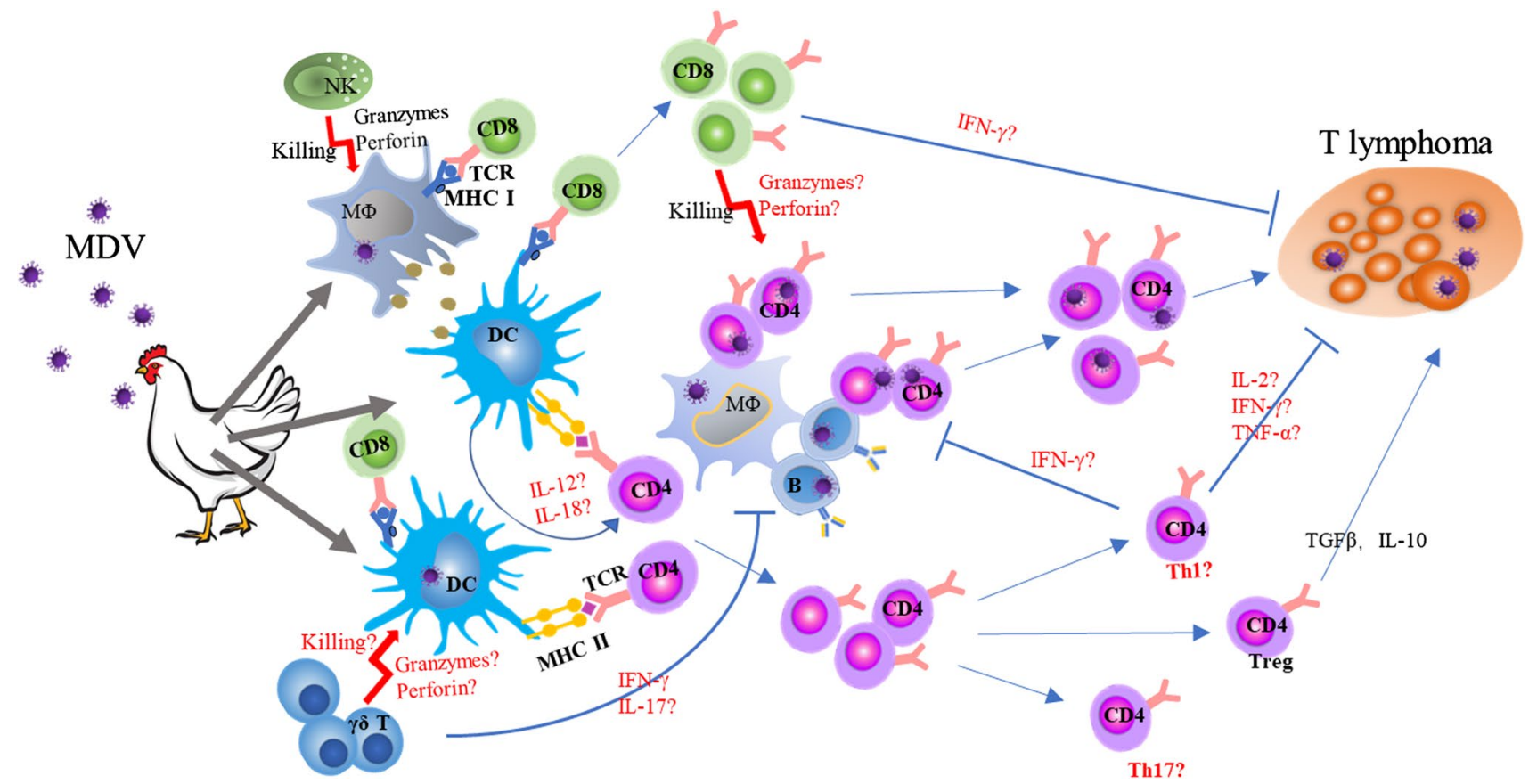

Fig. 1 Cellular immune response to Marek's disease virus: a proposal. After inhalation of cell-free virus particle, macrophages and DCs are infected. MDV-infected macrophages transmit the virus to $\mathrm{B}$ cells and $\mathrm{T}$ cells via cell-cell contact, eventually leading to CD4 T-cell transformation and lymphoma. While macrophages, NK cells, and high percentage of $\gamma \delta \mathrm{T}$ cells participate in the first-line host defense, infected or uninfected adjacent antigen-presenting cells present MDV antigen to CD4 and CD8 T cells through classical antigen presentation or cross-presentation, leading to T-cell activation and differentiation. However, which epitope or MDV antigen are presented and recognized by $\mathrm{T}$ cells has not been identified. Activated CD8 T cells play a critical role in the protection against MD tumor, but their effector functions are not fully addressed. Activated CD4 T cells may differentiate into effector $\mathrm{T}$ cells and distinct T-helper subsets such as Th1, Th2, Th17, Treg, and so on. While TGF- $\beta^{+}$Tregs were shown to contribute to immunosuppression induced by MDV, whether other helper $\mathrm{T}$ cells exist after MDV infection or vaccination and how they function in anti-MDV immunity have not been studied. Although effector molecules and cytokines including IFN- $\gamma$, TNF- $\alpha$, IL-2, granzymes, perforin, IL-17, IL-12, and IL-18 were detected at mRNA level after vaccination, by which immune cell subset they are produced has not been examined at single-cell level or protein level. To answer the above-mentioned questions relies on the advances of methods for studying cellular immunity and availability of immunological reagents in chickens 
thrombocytes [141]. IFN- $\gamma$ intracellular staining (ICS) and ELISPOT assay have facilitated the detection of virusspecific T-cell response and epitope mapping [51, 142, 143]. Using CD107a as a surrogate marker has simplified cytotoxicity assays of T cells in chickens [144]. In vitro differentiation of DCs and macrophages provides sources of syngeneic APCs and targets cells for the studies of antigen presentation and CTL activity [69, 71]. Finally, long-term culture of $\mathrm{T}$ cells in vitro reported in the literature [74, 99] can be applied to generate antigen-specific T-cell clones in chickens, thus favoring studies of antigen recognition of $\mathrm{T}$ cells. These methodological improvements (Table 1) have paved a path for further investigation of cellular immunity to MDV as well as other avian viruses in chickens.

In summary, we revisited and described the roles of various subsets of immune cells in host defense against MDV infection and proposed areas of research that need to be further explored, as shown in Fig. 1. With the advance and application of new immunological approaches and reagents available in chickens, new findings about the cellular immunity against MDV after infection and vaccination will be discovered. This will facilitate the development of the next generation of vaccines against MDV and improve our understanding of anti-tumor immunity in chickens as well.

Acknowledgements We are grateful to Dr. Lavanya Visvabharathy at Northwestern University and Dr. Sreya Bagchi at Stanford University for critical review of the manuscript. This work was funded by The Basic Research Program of Jiangsu Province (BK20190881 to Y. Y.), The China Postdoctoral Science Foundation (2018M642345 to X. H. and 2019M650126 to Y. Y.), The Natural Science Foundation of Jiangsu Higher Education Institutions of China (19KJB230001 to Y. Y.), National Natural Science Foundation of China (31472192 and 31972717 to A. Q.), and A Project Funded by the Priority Academic Program Development of Jiangsu Higher Education Institutions (PAPD).

Author contributions SS designed the structure of review and took the lead in drafting the manuscript. YY, MD, and XH drafted several sections of the manuscript and prepared the figure and table. AQ helped with the revision of the draft. All authors read and approved the final manuscript.

\section{Compliance with ethical standards}

Conflict of interest The authors declare no conflict of interest.

Open Access This article is licensed under a Creative Commons Attribution 4.0 International License, which permits use, sharing, adaptation, distribution and reproduction in any medium or format, as long as you give appropriate credit to the original author(s) and the source, provide a link to the Creative Commons licence, and indicate if changes were made. The images or other third party material in this article are included in the article's Creative Commons licence, unless indicated otherwise in a credit line to the material. If material is not included in the article's Creative Commons licence and your intended use is not permitted by statutory regulation or exceeds the permitted use, you will need to obtain permission directly from the copyright holder. To view a copy of this licence, visit http://creativecommons.org/licenses/by/4.0/.

\section{References}

1. Davison TF, Kaiser P (2004) Immunity to Marek's disease. In: Nair V, Davison F (eds) Marek's disease: an evolving problem. Elsevier, London, pp 126-139

2. Walker PJ, Siddell SG, Lefkowitz EJ, Mushegian AR, Dempsey DM, Dutilh BE, Harrach B, Harrison RL, Hendrickson RC, Junglen S, Knowles NJ, Kropinski AM, Krupovic M, Kuhn JH, Nibert M, Rubino L, Sabanadzovic S, Simmonds P, Varsani A, Zerbini FM, Davison AJ (2019) Changes to virus taxonomy and the International Code of Virus Classification and Nomenclature ratified by the International Committee on Taxonomy of Viruses (2019). Arch Virol 164(9):2417-2429. https://doi.org/10.1007/ s00705-019-04306-w

3. Davison AJ, Eberle R, Ehlers B, Hayward GS, McGeoch DJ, Minson AC, Pellett PE, Roizman B, Studdert MJ, Thiry E (2009) The order Herpesvirales. Arch Virol 154(1):171-177. https://doi. org/10.1007/s00705-008-0278-4

4. Osterrieder N, Kamil JP, Schumacher D, Tischer BK, Trapp S (2006) Marek's disease virus: from miasma to model. Nat Rev Microbiol 4(4):283-294. https://doi.org/10.1038/nrmicro1382

5. Schat KA, Calnek BW (1978) Characterization of an apparently nononcogenic Marek's disease virus. J Natl Cancer Inst 60(5):1075-1082

6. Rispens BH, van Vloten H, Mastenbroek N, Maas HJ, Schat KA (1972) Control of Marek's disease in the Netherlands. I. Isolation of an avirulent Marek's disease virus (strain CVI 988 ) and its use in laboratory vaccination trials. Avian Dis 16(1):108-125

7. Witter RL, Silva RF, Lee LF (1987) New serotype 2 and attenuated serotype 1 Marek's disease vaccine viruses: selected biological and molecular characteristics. Avian Dis 31(4):829-840

8. Witter RL, Kreager KS (2004) Serotype 1 viruses modified by backpassage or insertional mutagenesis: approaching the threshold of vaccine efficacy in Marek's disease. Avian Dis 48(4):768-782. https://doi.org/10.1637/7203-050304R

9. Cui H, Gao H, Cui X, Zhao Y, Shi X, Li Q, Yan S, Gao M, Wang M, Liu C, Wang Y (2013) Avirulent Marek's disease virus type 1 strain 814 vectored vaccine expressing avian influenza (AI) virus $\mathrm{H} 5$ haemagglutinin induced better protection than turkey herpesvirus vectored AI vaccine. PLoS ONE 8(1):e53340. https://doi.org/10.1371/journal.pone.0053340

10. Boodhoo N, Gurung A, Sharif S, Behboudi S (2016) Marek's disease in chickens: a review with focus on immunology. Vet Res 47(1):119. https://doi.org/10.1186/s13567-016-0404-3

11. Haq K, Schat KA, Sharif S (2013) Immunity to Marek's disease: where are we now? Dev Comp Immunol 41(3):439-446. https:// doi.org/10.1016/j.dci.2013.04.001

12. Gimeno IM (2008) Marek's disease vaccines: a solution for today but a worry for tomorrow? Vaccine 26(Suppl 3):C31-41

13. Witter RL (1997) Increased virulence of Marek's disease virus field isolates. Avian Dis 41(1):149-163

14. Davison F, Nair V (2005) Use of Marek's disease vaccines: could they be driving the virus to increasing virulence? Expert Rev Vaccines 4(1):77-88. https://doi.org/10.1586/14760584.4.1.77

15. Zhang YP, Li ZJ, Bao KY, Lv HC, Gao YL, Gao HL, Qi XL, Cui HY, Wang YQ, Ren XG, Wang XM, Liu CJ (2015) Pathogenic characteristics of Marek's disease virus field strains prevalent in China and the effectiveness of existing vaccines against them. 
Vet Microbiol 177(1-2):62-68. https://doi.org/10.1016/j.vetmi c. 2014.12 .020

16. Madej JP, Wozniakowski G, Gawel A (2016) Morphology of immune organs after very virulent plus strain of Marek's disease virus infection in vaccinated hens. Pol J Vet Sci 19(2):325-335. https://doi.org/10.1515/pjvs-2016-0040

17. Cui N, Su S, Sun P, Zhang Y, Han N, Cui Z (2016) Isolation and pathogenic analysis of virulent Marek's disease virus field strain in China. Poult Sci 95(7):1521-1528. https://doi.org/10.3382/ps/ pew073

18. Zhuang X, Zou H, Shi H, Shao H, Ye J, Miao J, Wu G, Qin A (2015) Outbreak of Marek's disease in a vaccinated broiler breeding flock during its peak egg-laying period in China. BMC Vet Res 11:157. https://doi.org/10.1186/s1291 7-015-0493-7

19. Reddy SM, Izumiya Y, Lupiani B (2017) Marek's disease vaccines: current status, and strategies for improvement and development of vector vaccines. Vet Microbiol 206:113-120. https://doi. org/10.1016/j.vetmic.2016.11.024

20. Bublot M (2014) Recent developments in Marek's disease vaccination. Int Hatch Pract 28(8):24-25

21. Lewis DE, Blutt SE (2019) 2-Organization of the immune system. In: Rich RR, Fleisher TA, Shearer WT, Schroeder HW, Frew AJ, Weyand CM (eds) Clinical immunology, 5th edn. Content Repository Only!, London, pp 19-38.e11. https://doi. org/10.1016/B978-0-7020-6896-6.00002-8

22. Godfrey DI, Uldrich AP, McCluskey J, Rossjohn J, Moody DB (2015) The burgeoning family of unconventional T cells. Nat Immunol 16(11):1114-1123. https://doi.org/10.1038/ni.3298

23. Rodgers JR, Cook RG (2005) MHC class Ib molecules bridge innate and acquired immunity. Nat Rev Immunol 5(6):459-471. https://doi.org/10.1038/nri1635

24. Kawai T, Akira S (2009) The roles of TLRs, RLRs and NLRs in pathogen recognition. Int Immunol 21(4):317-337. https://doi. org/10.1093/intimm/dxp017

25. Guidotti LG, Chisari FV (2001) Noncytolytic control of viral infections by the innate and adaptive immune response. Annu Rev Immunol 19:65-91. https://doi.org/10.1146/annurev.immun ol.19.1.65

26. Asselin-Paturel C, Brizard G, Chemin K, Boonstra A, O'Garra A, Vicari A, Trinchieri G (2005) Type I interferon dependence of plasmacytoid dendritic cell activation and migration. J Exp Med 201(7):1157-1167. https://doi.org/10.1084/jem.20041930

27. Le Page C, Genin P, Baines MG, Hiscott J (2000) Interferon activation and innate immunity. Rev Immunogenet 2(3):374-386

28. Rosendahl Huber S, van Beek J, de Jonge J, Luytjes W, van Baarle D (2014) T cell responses to viral infections-opportunities for peptide vaccination. Front Immunol 5:171. https://doi. org/10.3389/fimmu.2014.00171

29. Di Pucchio T, Chatterjee B, Smed-Sorensen A, Clayton S, Palazzo A, Montes M, Xue Y, Mellman I, Banchereau J, Connolly JE (2008) Direct proteasome-independent cross-presentation of viral antigen by plasmacytoid dendritic cells on major histocompatibility complex class I. Nat Immunol 9(5):551-557. https://doi.org/10.1038/ni.1602

30. Inaba K, Turley S, Iyoda T, Yamaide F, Shimoyama S, Reis e Sousa C, Germain RN, Mellman I, Steinman RM (2000) The formation of immunogenic major histocompatibility complex class II-peptide ligands in lysosomal compartments of dendritic cells is regulated by inflammatory stimuli. J Exp Med 191(6):927-936. https://doi.org/10.1084/jem.191.6.927

31. Butz EA, Bevan MJ (1998) Massive expansion of antigen-specific $\mathrm{CD} 8^{+} \mathrm{T}$ cells during an acute virus infection. Immunity 8(2):167-175. https://doi.org/10.1016/s1074-7613(00)80469-0

32. Harper N, Hughes M, MacFarlane M, Cohen GM (2003) Fasassociated death domain protein and caspase- 8 are not recruited to the tumor necrosis factor receptor 1 signaling complex during tumor necrosis factor-induced apoptosis. J Biol Chem 278(28):25534-25541. https://doi.org/10.1074/jbc.M3033 99200

33. Kang S, Brown HM, Hwang S (2018) Direct antiviral mechanisms of interferon-gamma. Immune Netw 18(5):e33. https:// doi.org/10.4110/in.2018.18.e33

34. Harrington LE, Janowski KM, Oliver JR, Zajac AJ, Weaver CT (2008) Memory CD4 T cells emerge from effector T-cell progenitors. Nature 452(7185):356-360. https://doi.org/10.1038/ nature 06672

35. Luckheeram RV, Zhou R, Verma AD, Xia B (2012) CD4(+) T cells: differentiation and functions. Clin Dev Immunol 2012:925135. https://doi.org/10.1155/2012/925135

36. Veiga-Parga T, Sehrawat S, Rouse BT (2013) Role of regulatory $\mathrm{T}$ cells during virus infection. Immunol Rev 255(1):182-196. https://doi.org/10.1111/imr.12085

37. Zhang S, Zhang H, Zhao J (2009) The role of CD4 T cell help for CD8 CTL activation. Biochem Biophys Res Commun 384(4):405-408. https://doi.org/10.1016/j.bbrc.2009.04.134

38. Crotty S (2015) A brief history of T cell help to B cells. Nat Rev Immunol 15(3):185-189. https://doi.org/10.1038/nri3803

39. Guo L, Junttila IS, Paul WE (2012) Cytokine-induced cytokine production by conventional and innate lymphoid cells. Trends Immunol 33(12):598-606. https://doi.org/10.1016/j. it.2012.07.006

40. Yoshimoto T, Takeda K, Tanaka T, Ohkusu K, Kashiwamura S, Okamura H, Akira S, Nakanishi K (1998) IL-12 up-regulates IL-18 receptor expression on T cells, Th1 cells, and B cells: synergism with IL-18 for IFN-gamma production. J Immunol 161(7):3400-3407

41. Harty JT, Badovinac VP (2008) Shaping and reshaping CD8 ${ }^{+}$ T-cell memory. Nat Rev Immunol 8(2):107-119. https://doi. org/10.1038/nri2251

42. Kaech SM, Wherry EJ, Ahmed R (2002) Effector and memory T-cell differentiation: implications for vaccine development. Nat Rev Immunol 2(4):251-262. https://doi.org/10.1038/nri778

43. Sallusto F, Geginat J, Lanzavecchia A (2004) Central memory and effector memory $\mathrm{T}$ cell subsets: function, generation, and maintenance. Annu Rev Immunol 22:745-763. https://doi. org/10.1146/annurev.immunol.22.012703.104702

44. Seder RA, Darrah PA, Roederer M (2008) T-cell quality in memory and protection: implications for vaccine design. Nat Rev Immunol 8(4):247-258. https://doi.org/10.1038/nri2274

45. Wherry EJ (2011) T cell exhaustion. Nat Immunol 12(6):492-499

46. Angelosanto JM, Blackburn SD, Crawford A, Wherry EJ (2012) Progressive loss of memory $\mathrm{T}$ cell potential and commitment to exhaustion during chronic viral infection. J Virol 86(15):81618170. https://doi.org/10.1128/JVI.00889-12

47. Kaspers B, Göbel TWF (2016) The avian immune system. In: Ratcliffe MJH (ed) Encyclopedia of immunobiology. Academic Press, Oxford, pp 498-503. https://doi.org/10.1016/B978-0-12374279-7.12013-2

48. Smith AL, Göbel TW (2014) Chapter 5-avian T cells: antigen recognition and lineages. In: Schat KA, Kaspers B, Kaiser P (eds) Avian immunology, 2nd edn. Academic Press, Boston, pp 91-102. https://doi.org/10.1016/B978-0-12-396965-1.00005-4

49. Omar AR, Schat KA (1996) Syngeneic Marek's disease virus (MDV)-specific cell-mediated immune responses against immediate early, late, and unique MDV proteins. Virology 222(1):8799. https://doi.org/10.1006/viro.1996.0400

50. Omar AR, Schat KA (1997) Characterization of Marek's disease herpesvirus-specific cytotoxic T lymphocytes in chickens inoculated with a non-oncogenic vaccine strain of MDV. Immunology 90(4):579-585 
51. Reemers SS, van Haarlem DA, Sijts AJ, Vervelde L, Jansen CA (2012) Identification of novel avian influenza virus derived CD8 ${ }^{+}$ T-cell epitopes. PLoS ONE 7(2):e31953. https://doi.org/10.1371/ journal.pone.0031953

52. Garcia-Camacho L, Schat KA, Brooks R Jr, Bounous DI (2003) Early cell-mediated immune responses to Marek's disease virus in two chicken lines with defined major histocompatibility complex antigens. Vet Immunol Immunopathol 95(3-4):145-153

53. Barrow AD, Burgess SC, Baigent SJ, Howes K, Nair VK (2003) Infection of macrophages by a lymphotropic herpesvirus: a new tropism for Marek's disease virus. J Gen Virol 84(Pt 10):26352645. https://doi.org/10.1099/vir.0.19206-0

54. Djeraba A, Bernardet N, Dambrine G, Quere P (2000) Nitric oxide inhibits Marek's disease virus replication but is not the single decisive factor in interferon-gamma-mediated viral inhibition. Virology 277(1):58-65. https://doi.org/10.1006/viro.2000.0576

55. Kodama H, Mikami T, Inoue M, Izawa H (1979) Inhibitory effects of macrophages against Marek's disease virus plaque formation in chicken kidney cell cultures. J Natl Cancer Inst 63(5):1267-1271

56. Chakraborty P, Vervelde L, Dalziel RG, Wasson PS, Nair V, Dutia BM, Kaiser P (2017) Marek's disease virus infection of phagocytes: a de novo in vitro infection model. J Gen Virol 98(5):1080-1088. https://doi.org/10.1099/jgv.0.000763

57. Powell PC, Hartley KJ, Mustill BM, Rennie M (1983) Studies on the role of macrophages in Marek's disease of the chicken. J Reticuloendothel Soc 34(4):289-297

58. Gupta MK, Chauhan HV, Jha GJ, Singh KK (1989) The role of the reticuloendothelial system in the immunopathology of Marek's disease. Vet Microbiol 20(3):223-234

59. Abdul-Careem MF, Haq K, Shanmuganathan S, Read LR, Schat KA, Heidari M, Sharif S (2009) Induction of innate host responses in the lungs of chickens following infection with a very virulent strain of Marek's disease virus. Virology 393(2):250257. https://doi.org/10.1016/j.virol.2009.08.001

60. Djeraba A, Musset E, Bernardet N, Le Vern Y, Quere P (2002) Similar pattern of iNOS expression, NO production and cytokine response in genetic and vaccination-acquired resistance to Marek's disease. Vet Immunol Immunopathol 85(1-2):63-75

61. Jarosinski KW, Njaa BL, O'Connell PH, Schat KA (2005) Pro-inflammatory responses in chicken spleen and brain tissues after infection with very virulent plus Marek's disease virus. Viral Immunol 18(1):148-161. https://doi.org/10.1089/ vim.2005.18.148

62. Xing Z, Schat KA (2000) Inhibitory effects of nitric oxide and gamma interferon on in vitro and in vivo replication of Marek's disease virus. J Virol 74(8):3605-3612

63. Wang D, Sun S, Heidari M (2018) Marek's disease vaccine activates chicken macrophages. J Vet Sci 19(3):375-383. https://doi. org/10.4142/jvs.2018.19.3.375

64. Fonseca SG, Romao PR, Figueiredo F, Morais RH, Lima HC, Ferreira SH, Cunha FQ (2003) TNF-alpha mediates the induction of nitric oxide synthase in macrophages but not in neutrophils in experimental cutaneous leishmaniasis. Eur J Immunol 33(8):2297-2306. https://doi.org/10.1002/eji.200320335

65. Rohde F, Schusser B, Hron T, Farkasova H, Plachy J, Hartle S, Hejnar J, Elleder D, Kaspers B (2018) Characterization of chicken tumor necrosis factor-alpha, a long missed cytokine in birds. Front Immunol 9:605. https://doi.org/10.3389/fimmu .2018 .00605

66. Chakraborty P, Kuo R, Vervelde L, Dutia BM, Kaiser P, Smith J (2019) Macrophages from susceptible and resistant chicken lines have different transcriptomes following Marek's disease virus infection. Genes (Basel). https://doi.org/10.3390/genes10020074

67. Lee LF, Sharma JM, Nazerian K, Witter RL (1978) Suppression of mitogen-induced proliferation of normal spleen cells by macrophages from chickens inoculated with Marek's disease virus. J Immunol 120(5):1554-1559

68. Noy R, Pollard JW (2014) Tumor-associated macrophages: from mechanisms to therapy. Immunity 41(1):49-61. https:// doi.org/10.1016/j.immuni.2014.06.010

69. Wu Z, Rothwell L, Young JR, Kaufman J, Butter C, Kaiser P (2010) Generation and characterization of chicken bone marrowderived dendritic cells. Immunology 129(1):133-145. https://doi. org/10.1111/j.1365-2567.2009.03129.x

70. Igyarto BZ, Lacko E, Olah I, Magyar A (2006) Characterization of chicken epidermal dendritic cells. Immunology 119(2):278288. https://doi.org/10.1111/j.1365-2567.2006.02432.x

71. de Geus ED, Jansen CA, Vervelde L (2012) Uptake of particulate antigens in a nonmammalian lung: phenotypic and functional characterization of avian respiratory phagocytes using bacterial or viral antigens. J Immunol 188(9):4516-4526. https ://doi.org/10.4049/jimmunol.1200092

72. Vu Manh TP, Marty H, Sibille P, Le Vern Y, Kaspers B, Dalod M, Schwartz-Cornil I, Quere P (2014) Existence of conventional dendritic cells in Gallus gallus revealed by comparative gene expression profiling. J Immunol 192(10):4510-4517. https://doi.org/10.4049/jimmunol.1303405

73. Nagy N, Bodi I, Olah I (2016) Avian dendritic cells: phenotype and ontogeny in lymphoid organs. Dev Comp Immunol 58:47-59. https://doi.org/10.1016/j.dci.2015.12.020

74. Gobel TW, Schneider K, Schaerer B, Mejri I, Puehler F, Weigend S, Staeheli P, Kaspers B (2003) IL-18 stimulates the proliferation and IFN-gamma release of $\mathrm{CD} 4^{+} \mathrm{T}$ cells in the chicken: conservation of a Th1-like system in a nonmammalian species. J Immunol 171(4):1809-1815. https://doi.org/10.4049/ jimmunol.171.4.1809

75. Kano R, Konnai S, Onuma M, Ohashi K (2009) Cytokine profiles in chickens infected with virulent and avirulent Marek's disease viruses: interferon-gamma is a key factor in the protection of Marek's disease by vaccination. Microbiol Immunol 53(4):224-232

76. Abdul-Careem MF, Hunter BD, Parvizi P, Haghighi HR, Thanthrige-Don N, Sharif S (2007) Cytokine gene expression patterns associated with immunization against Marek's disease in chickens. Vaccine 25(3):424-432. https://doi.org/10.1016/j. vaccine.2006.08.006

77. Lanier LL (2005) NK cell recognition. Annu Rev Immunol 23:225-274. https://doi.org/10.1146/annurev.immun ol.23.021704.115526

78. Sharma JM, Okazaki W (1981) Natural killer cell activity in chickens: target cell analysis and effect of antithymocyte serum on effector cells. Infect Immun 31(3):1078-1085

79. Heller ED, Schat KA (1987) Enhancement of natural killer cell activity by Marek's disease vaccines. Avian Pathol 16(1):5160. https://doi.org/10.1080/03079458708436352

80. Rogers SL, Viertlboeck BC, Gobel TW, Kaufman J (2008) Avian NK activities, cells and receptors. Semin Immunol 20(6):353-360. https://doi.org/10.1016/j.smim.2008.09.005

81. Neulen ML, Viertlboeck BC, Straub C, Gobel TW (2015) Identification of novel chicken CD4(+) CD3(-) blood population with NK cell like features. Dev Comp Immunol 49(1):72-78. https://doi.org/10.1016/j.dci.2014.11.012

82. Jansen CA, van de Haar PM, van Haarlem D, van Kooten P, de Wit S, van Eden W, Viertlbock BC, Gobel TW, Vervelde L (2010) Identification of new populations of chicken natural killer (NK) cells. Dev Comp Immunol 34(7):759-767. https:// doi.org/10.1016/j.dci.2010.02.009

83. Sarson AJ, Abdul-Careem MF, Read LR, Brisbin JT, Sharif S (2008) Expression of cytotoxicity-associated genes in Marek's disease virus-infected chickens. Viral Immunol 21(2):267-272. https://doi.org/10.1089/vim.2007.0094 
84. Fenzl L, Gobel TW, Neulen ML (2017) gammadelta T cells represent a major spontaneously cytotoxic cell population in the chicken. Dev Comp Immunol 73:175-183. https://doi. org/10.1016/j.dci.2017.03.028

85. Bertzbach LD, van Haarlem DA, Hartle S, Kaufer BB, Jansen CA (2019) Marek's disease virus infection of natural killer cells. Microorganisms. https://doi.org/10.3390/microorgan isms 7120588

86. Hunt HD, Lupiani B, Miller MM, Gimeno I, Lee LF, Parcells MS (2001) Marek's disease virus down-regulates surface expression of MHC (B Complex) Class I (BF) glycoproteins during active but not latent infection of chicken cells. Virology 282(1):198-205. https://doi.org/10.1006/viro.2000.0797

87. Yu C, Liu Q, Qin A, Hu X, Xu W, Qian K, Shao H, Jin W (2013) Expression kinetics of chicken beta2-microglobulin and Class I MHC in vitro and in vivo during Marek's disease viral infections. Vet Res Commun 37(4):277-283. https://doi. org/10.1007/s11259-013-9572-z

88. Kim T, Hunt HD, Parcells MS, van Santen V, Ewald SJ (2018) Two class I genes of the chicken MHC have different functions: $\mathrm{BF} 1$ is recognized by $\mathrm{NK}$ cells while $\mathrm{BF} 2$ is recognized by CTLs. Immunogenetics 70(9):599-611. https://doi. org/10.1007/s00251-018-1066-2

89. Shiromizu CM, Jancic CC (2018) Gammadelta T lymphocytes: an effector cell in autoimmunity and infection. Front Immunol 9:2389. https://doi.org/10.3389/fimmu.2018.02389

90. Laursen AMS, Kulkarni RR, Taha-Abdelaziz K, Plattner BL, Read LR, Sharif S (2018) Characterizaton of gamma delta T cells in Marek's disease virus (Gallid herpesvirus 2) infection of chickens. Virology 522:56-64. https://doi.org/10.1016/j. virol.2018.06.014

91. Walliser I, Gobel TW (2018) Chicken IL-17A is expressed in alphabeta and gammadelta $\mathrm{T}$ cell subsets and binds to a receptor present on macrophages, and T cells. Dev Comp Immunol 81:44-53. https://doi.org/10.1016/j.dci.2017.11.004

92. Bertzbach LD, Laparidou M, Hartle S, Etches RJ, Kaspers B, Schusser B, Kaufer BB (2018) Unraveling the role of B cells in the pathogenesis of an oncogenic avian herpesvirus. Proc Natl Acad Sci USA 115(45):11603-11607. https://doi.org/10.1073/ pnas. 1813964115

93. Engel AT, Selvaraj RK, Kamil JP, Osterrieder N, Kaufer BB (2012) Marek's disease viral interleukin-8 promotes lymphoma formation through targeted recruitment of B cells and $\mathrm{CD}^{+}{ }^{+} \mathrm{CD} 25^{+} \mathrm{T}$ cells. J Virol 86(16):8536-8545. https://doi. org/10.1128/JVI.00556-12

94. Haertle S, Alzuheir I, Busalt F, Waters V, Kaiser P, Kaufer BB (2017) Identification of the receptor and cellular ortholog of the Marek's disease virus (MDV) CXC chemokine. Front Microbiol 8:2543. https://doi.org/10.3389/fmicb.2017.02543

95. Baigent SJ, Ross LJ, Davison TF (1998) Differential susceptibility to Marek's disease is associated with differences in number, but not phenotype or location, of pp38+ lymphocytes. J Gen Virol 79(Pt 11):2795-2802. https://doi. org/10.1099/0022-1317-79-11-2795

96. Calnek BW, Schat KA, Ross LJ, Chen CL (1984) Further characterization of Marek's disease virus-infected lymphocytes. II. In vitro infection. Int J Cancer 33(3):399-406

97. Berthault C, Larcher T, Hartle S, Vautherot JF, Trapp-Fragnet L, Denesvre C (2018) Atrophy of primary lymphoid organs induced by Marek's disease virus during early infection is associated with increased apoptosis, inhibition of cell proliferation and a severe B-lymphopenia. Vet Res 49(1):31. https ://doi.org/10.1186/s13567-018-0526-x

98. Baaten BJ, Staines KA, Smith LP, Skinner H, Davison TF, Butter C (2009) Early replication in pulmonary B cells after infection with Marek's disease herpesvirus by the respiratory route. Viral Immunol 22(6):431-444. https://doi.org/10.1089/ vim. 2009.0047

99. Schermuly J, Greco A, Hartle S, Osterrieder N, Kaufer BB, Kaspers B (2015) In vitro model for lytic replication, latency, and transformation of an oncogenic alphaherpesvirus. Proc Natl Acad Sci USA 112(23):7279-7284. https://doi.org/10.1073/ pnas. 1424420112

100. Purchase HG, Sharma JM (1974) Amelioration of Marek's disease and absence of vaccine protection in immunologically deficient chickens. Nature 248(447):419-421. https://doi. org/10.1038/248419a0

101. Schat KA, Calnek BW, Fabricant J (1981) Influence of the bursa of Fabricius on the pathogenesis of Marek's disease. Infect Immun 31(1):199-207

102. Schat KA, Markowski-Grimsrud CJ (2001) Immune responses to Marek's disease virus infection. Curr Top Microbiol Immunol 255:91-120

103. Calnek BW (1972) Effects of passive antibody on early pathogenesis of Marek's disease. Infect Immun 6(2):193-198

104. Wu C, Gan J, Jin Q, Chen C, Liang P, Wu Y, Liu X, Ma L, Davison F (2009) Revaccination with Marek's disease vaccines induces productive infection and superior immunity. Clin Vaccine Immunol 16(2):184-193. https://doi.org/10.1128/ CVI.00201-08

105. Witter RL, Lee LF (1984) Polyvalent Marek's disease vaccines: safety, efficacy and protective synergism in chickens with maternal antibodies. Avian Pathol 13(1):75-92. https://doi. org/10.1080/03079458408418510

106. Payne LN, Rennie M (1973) Pathogenesis of Marek's disease in chicks with and without maternal antibody. J Natl Cancer Inst 51(5):1559-1573. https://doi.org/10.1093/jnci/51.5.1559

107. Kinchington PR, Leger AJ, Guedon JM, Hendricks RL (2012) Herpes simplex virus and varicella zoster virus, the house guests who never leave. Herpesviridae 3(1):5. https://doi. org/10.1186/2042-4280-3-5

108. Rajasagi NK, Kassim SH, Kollias CM, Zhao X, Chervenak R, Jennings SR (2009) $\mathrm{CD}^{+} \mathrm{T}$ cells are required for the priming of $\mathrm{CD} 8^{+} \mathrm{T}$ cells following infection with herpes simplex virus type 1. J Virol 83(10):5256-5268. https://doi.org/10.1128/JVI.01997 $-08$

109. Ross LJ (1977) Antiviral T cell-mediated immunity in Marek's disease. Nature 268(5621):644-646

110. Sharma JM, Witter RL, Coulson BD (1978) Development of cellmediated immunity to Marek's disease tumor cells in chickens inoculated with Marek's disease vaccines. J Natl Cancer Inst 61(5):1273-1280

111. Powell PC, Rowell JG (1977) Dissociation of antiviral and antitumor immunity in resistance to Marek's disease. J Natl Cancer Inst 59(3):919-924

112. Morimura T, Ohashi K, Sugimoto C, Onuma M (1998) Pathogenesis of Marek's disease (MD) and possible mechanisms of immunity induced by MD vaccine. J Vet Med Sci 60(1):1-8

113. Morimura T, Cho KO, Kudo Y, Hiramoto Y, Ohashi K, Hattori M, Sugimoto C, Onuma M (1999) Anti-viral and anti-tumor effects induced by an attenuated Marek's disease virus in CD4or CD8-deficient chickens. Arch Virol 144(9):1809-1818. https ://doi.org/10.1007/s007050050705

114. Markowski-Grimsrud CJ, Schat KA (2002) Cytotoxic T lymphocyte responses to Marek's disease herpesvirus-encoded glycoproteins. Vet Immunol Immunopathol 90(3-4):133-144

115. Morimura T, Hattori M, Ohashi K, Sugimoto C, Onuma M (1995) Immunomodulation of peripheral $T$ cells in chickens infected with Marek's disease virus: involvement in immunosuppression. J Gen Virol 76(Pt 12):2979-2985. https://doi. org/10.1099/0022-1317-76-12-2979 
116. Schat KA, Xing Z (2000) Specific and nonspecific immune responses to Marek's disease virus. Dev Comp Immunol 24(2-3):201-221

117. Sherman MA, Goto RM, Moore RE, Hunt HD, Lee TD, Miller MM (2008) Mass spectral data for 64 eluted peptides and structural modeling define peptide binding preferences for class I alleles in two chicken MHC-B haplotypes associated with opposite responses to Marek's disease. Immunogenetics 60(9):527541. https://doi.org/10.1007/s00251-008-0302-6

118. Cumberbatch JA, Brewer D, Vidavsky I, Sharif S (2006) Chicken major histocompatibility complex class II molecules of the B haplotype present self and foreign peptides. Anim Genet 37(4):393-396. https://doi.org/10.1111/j.1365-2052.2006.01459 .x

119. Haeri M, Read LR, Wilkie BN, Sharif S (2005) Identification of peptides associated with chicken major histocompatibility complex class II molecules of B21 and B19 haplotypes. Immunogenetics 56(11):854-859. https://doi.org/10.1007/s0025 1-004-0760-4

120. Bashir S, Ali Abd-elrahman K, Hassan AM, Almofti AY (2018) Multi epitope based peptide vaccine against Marek's disease virus serotype 1 glycoprotein $\mathrm{H}$ and $\mathrm{B}$. Am J Microbiol Res 6(4):124-139

121. Witter RL, Stephens EA, Sharma JM, Nazerian K (1975) Demonstration of a tumor-associated surface antigen in Marek's disease. J Immunol 115(1):177-183

122. Burgess SC, Young JR, Baaten BJ, Hunt L, Ross LN, Parcells MS, Kumar PM, Tregaskes CA, Lee LF, Davison TF (2004) Marek's disease is a natural model for lymphomas overexpressing Hodgkin's disease antigen (CD30). Proc Natl Acad Sci USA 101(38):13879-13884. https://doi.org/10.1073/pnas.0305789101

123. Pauker VI, Bertzbach LD, Hohmann A, Kheimar A, Teifke JP, Mettenleiter TC, Karger A, Kaufer BB (2019) Imaging mass spectrometry and proteome analysis of Marek's disease virus-induced tumors. mSphere. https://doi.org/10.1128/mSphe re.00569-18

124. Heidari M, Wang D, Sun S (2017) Early immune responses to Marek's disease vaccines. Viral Immunol 30(3):167-177. https ://doi.org/10.1089/vim.2016.0126

125. Haq K, Elawadli I, Parvizi P, Mallick AI, Behboudi S, Sharif S (2011) Interferon-gamma influences immunity elicited by vaccines against very virulent Marek's disease virus. Antivir Res 90(3):218-226. https://doi.org/10.1016/j.antiviral.2011.04.001

126. Parvizi P, Read L, Abdul-Careem MF, Lusty C, Sharif S (2009) Cytokine gene expression in splenic CD4(+) and CD8(+) T-cell subsets of chickens infected with Marek's disease virus. Viral Immunol 22(1):31-38. https://doi.org/10.1089/vim.2008.0062

127. Parvizi P, Read LR, Abdul-Careem MF, Sarson AJ, Lusty C, Lambourne M, Thanthrige-Don N, Burgess SC, Sharif S (2009) Cytokine gene expression in splenic $\mathrm{CD}^{+}$and $\mathrm{CD} 8^{+} \mathrm{T}$ cell subsets of genetically resistant and susceptible chickens infected with Marek's disease virus. Vet Immunol Immunopathol 132(24):209-217. https://doi.org/10.1016/j.vetimm.2009.06.009

128. Wherry EJ, Kurachi M (2015) Molecular and cellular insights into T cell exhaustion. Nat Rev Immunol 15(8):486-499. https ://doi.org/10.1038/nri3862

129. Okazaki T, Chikuma S, Iwai Y, Fagarasan S, Honjo T (2013) A rheostat for immune responses: the unique properties of PD-1 and their advantages for clinical application. Nat Immunol 14(12):1212-1218. https://doi.org/10.1038/ni.2762

130. Matsuyama-Kato A, Murata S, Isezaki M, Kano R, Takasaki S, Ichii O, Konnai S, Ohashi K (2012) Molecular characterization of immunoinhibitory factors PD-1/PD-L1 in chickens infected with Marek's disease virus. Virol J 9:94. https://doi. org/10.1186/1743-422X-9-94

131. Parvizi P, Andrzejewski K, Read LR, Behboudi S, Sharif S (2010) Expression profiling of genes associated with regulatory functions of T-cell subsets in Marek's disease virusinfected chickens. Avian Pathol 39(5):367-373. https://doi. org/10.1080/03079457.2010.508776

132. Sakaguchi S, Yamaguchi T, Nomura T, Ono M (2008) Regulatory T cells and immune tolerance. Cell 133(5):775-787. https://doi. org/10.1016/j.cell.2008.05.009

133. Shanmugasundaram R, Selvaraj RK (2011) Regulatory $T$ cell properties of chicken $\mathrm{CD} 4{ }^{+} \mathrm{CD} 25^{+}$cells. J Immunol 186(4):1997-2002. https://doi.org/10.4049/jimmunol.1002040

134. Andersen KG, Nissen JK, Betz AG (2012) Comparative genomics reveals key gain-of-function events in Foxp3 during regulatory T cell evolution. Front Immunol 3:113. https://doi. org/10.3389/fimmu.2012.00113

135. Denyer MP, Pinheiro DY, Garden OA, Shepherd AJ (2016) Missed, not missing: phylogenomic evidence for the existence of avian FoxP3. PLoS ONE 11(3):e0150988. https://doi org/10.1371/journal.pone.0150988

136. Gurung A, Kamble N, Kaufer BB, Pathan A, Behboudi S (2017) Association of Marek's disease induced immunosuppression with activation of a novel regulatory $\mathrm{T}$ cells in chickens. PLoS Pathog 13(12):e1006745. https://doi.org/10.1371/journal.ppat.1006745

137. Gimeno IM, Cortes AL, Reddy SM, de Juan L, Abad B, Kaser T, Limsatanun A (2019) Highly virulent Marek's disease virus strains affect $\mathrm{T}$ lymphocyte function and viability of splenocytes in commercial meat-type chickens. Avian Pathol 48(6):564-572. https://doi.org/10.1080/03079457.2019.1643451

138. Dai M, Xu C, Chen W, Liao M (2019) Progress on chicken T cell immunity to viruses. Cell Mol Life Sci 76(14):2779-2788. https ://doi.org/10.1007/s00018-019-03117-1

139. Dalgaard TS, Norup LR, Rubbenstroth D, Wattrang E, JuulMadsen HR (2010) Flow cytometric assessment of antigen-specific proliferation in peripheral chicken $\mathrm{T}$ cells by CFSE dilution. Vet Immunol Immunopathol 138(1-2):85-94. https://doi. org/10.1016/j.vetimm.2010.07.010

140. Dalgaard TS, Norup LR, Pedersen AR, Handberg KJ, Jorgensen PH, Juul-Madsen HR (2010) Flow cytometric assessment of chicken T cell-mediated immune responses after Newcastle disease virus vaccination and challenge. Vaccine 28(28):4506-4514. https://doi.org/10.1016/j.vaccine.2010.04.044

141. Seliger C, Schaerer B, Kohn M, Pendl H, Weigend S, Kaspers B, Hartle S (2012) A rapid high-precision flow cytometry based technique for total white blood cell counting in chickens. Vet Immunol Immunopathol 145(1-2):86-99. https://doi. org/10.1016/j.vetimm.2011.10.010

142. Ariaans MP, van de Haar PM, Lowenthal JW, van Eden W, Hensen EJ, Vervelde L (2008) ELISPOT and intracellular cytokine staining: novel assays for quantifying $\mathrm{T}$ cell responses in the chicken. Dev Comp Immunol 32(11):1398-1404. https:// doi.org/10.1016/j.dci.2008.05.007

143. Andersen SH, Vervelde L, Sutton K, Norup LR, Wattrang E, Juul-Madsen HR, Dalgaard TS (2017) Quantification and phenotypic characterisation of peripheral IFN-gamma producing leucocytes in chickens vaccinated against Newcastle disease. Vet Immunol Immunopathol 193-194:18-28. https://doi. org/10.1016/j.vetimm.2017.10.001

144. Wattrang E, Dalgaard TS, Norup LR, Kjaerup RB, Lunden A, Juul-Madsen HR (2015) CD107a as a marker of activation in chicken cytotoxic T cells. J Immunol Methods 419:35-47. https ://doi.org/10.1016/j.jim.2015.02.011

Publisher's Note Springer Nature remains neutral with regard to jurisdictional claims in published maps and institutional affiliations. 